Isidore Diala Migrating bards: Writers' burdens

Isidore Diala is Associate Professor and Head of the Department of English, Imo State University, Owerri, Nigeria. and a writers' body in Nigeria at the turn of the century

E-mail: isidorediala@yahoo.com

\section{Migrating bards: Writers' burdens and a writers' body in Nigeria at the turn of the century}

Wole Soyinka's 1986 Nobel Prize for literature was received as a well deserved international recognition not only of the distinction of Soyinka's sustained output but also as a tribute to Nigerian and African literature in general. However, given decades of irresponsible leadership in the country, a sober appraisal of the Nigerian cultural and intellectual front twenty years after the Nobel event reveals a shocking impoverishment of the institutions for the production and evaluation of literature. With a collapsed publishing industry and the continuing migration of Nigeria's most distinguished writers and literary critics to the West, Nigerian literature stands the risk of being subject to the dictates of legitimizing foreign agents of literary production and evaluation with the consequent danger of the perpetuation of Western biases of African literary excellence. By its crucial interventionist measures though, the Association of Nigerian Authors continues to strive to transform the socio-political environment so critical for the creation and appreciation of literature, to sustain the ideals of good writing in Nigeria and, moreover, by its annual awards of literary prizes, to remain a prominent stakeholder in the appraisal of literary excellence. Key words: Association of Nigerian Authors (ANA), Nigerian literature, Nigerian publishing industry, Wole Soyinka.

\section{1}

The enormous symbolic capital in cultural production has been noted quite often in contemporary literary discourse. Manifest in the assumption of the authority to codify and dictate a hierarchy of literary value, and consequently the power to admit or exclude from the canon, this economy, Graham Huggan (2001: 52-3), citing Pierre Bourdieu and C. B. Lizarribar, contends, is at work in the expectation or even extortion of a peculiar style and tone from African writers by legitimizing foreign agents of literary production; it is consistent with the iconic representation of an "authentic Africa" which conforms to Euro-American pre-occupations of "simplicity" and "primitivism".

So central indeed is cultural production in the concept of postcolonial literature to Charles Lock (2006) that he interrogates the validity of the postcolonial status ascribed to indigenous writers in the colonial period. Writing on the role missionaries played in conveying the manuscripts of the first novel to be published in English by 
a Nigerian, Amos Tutuola's The Palm-wine Drinkard, to Faber and persuading Faber to publish the work, Lock highlights the crucial indebtedness of that work and similar literature to the colonial heritage of representation and to colonial agents of cultural production. He reappraises the history of indigenous publication that "occluded the mechanism of colonial administration and of economic relations that actually brought those books into being and circulation" (Lock 2006: 182). For Lock, such texts as The Palm-wine Drinkard are indeed "colonial" not "postcolonial." Fifty-four years after the publication of The Palm-wine Drinkard, the status of many literary works published by Nigerians, using Lock's scale of values, certainly remains controversial.

The subtle but fierce contest to control the institutions of production and canonization of texts is in reality a struggle for the power to determine and sanction authorized representations of both the self and the Other; it is thus an endeavor consistent with the struggle for economic and ideological dominance. By placing itself uniquely to project and reward its preferred concept of African excellence by publication, distribution and award of prestigious prizes, the West exercises powers that have implications that go beyond the artistic. Derek Attridge contends that canonization means so much more than the recognition of an author's invaluable contribution to literature by publishers and scholars of literature. He draws attention to the cultural and historical contingency of the canon and links it with wider processes of legitimation within the body of culturally recognized narratives. But this form of cultural validation neutralizes and absorbs oppositionality: "All canons rest on exclusion; the voice they give to some can be heard only by virtue of the silence they impose on others. But it is just not a silencing by exclusion; it is a silencing by inclusion as well: any voice we can hear is by that very fact purged of its uniqueness and alterity" (Attridge 1992: 226).

Conceding that The Palm-wine Drinkard and Things Fall Apart would probably never have been published but for Western publishers, Chinua Achebe inscribes that as only the first stage in the history of African publishing and envisages an evolution in which Africa would be central in its cultural production needs: "if you are going to have a genuine literary tradition, then the entire book business should have an indigenous base. Not just writers being here, but their publishers, editors, bookshops, printers [...] [Y]ou can't really talk about African literature unless you have all these other aspects of the book trade in Africa. This is my stand" (Achebe on ANA website). Expectedly, in a recent public celebration and meditation on the state of Nigerian/African literature, Achebe's position was revalidated.

The award of the Nobel Prize for literature to Wole Soyinka in 1986 was appropriately generally appraised as a peak in the development of African literature. In Nigeria, the continuing celebration of the award culminated recently in the marking of its twentieth anniversary organized by the Association of Nigerian Authors (ANA) at the Obafemi Awolowo University, Ile-Ife, Nigeria. Entitled “International Colloquium 
on 20 Years After the Nobel Prize in Literature: Governance and Development in Africa," the event expectedly became an opportune occasion for a sober appraisal of African literature in the twentieth century and its prospects in the twentieth-first. Nadine Gordimer's meditation on these is characteristically focal.

In a tribute to Soyinka entitled "Turning the Page: African Writers in the $21^{\text {st }}$ Century," Gordimer identifies Soyinka's significance as his distinction in the most crucial task of the African writer in the twentieth century - an imaginative engagement in his life and work with the historical substance of being - and nourishment of the human spirit: "He endured imprisonment in his dedication to fight for bread and justice, and his works attain the pure beauty of imaginative power that fulfils that other hungry need, of the spirit" (Gordimer 2006: 6). Stressing Africa's need of the world for the purpose of technological development, she regards as anachronistic the creation of a "pure" indigenous culture. She nonetheless considers the crucial challenge of African literature in the $21^{\text {st }}$ century "the necessity to devise the means by which literature in African languages becomes the major component of the continent's literature. Without this one cannot speak of an African literature" (Gordimer 2006: 4). Casting a sober light on the production and distribution of literature in the continent, Gordimer's chastened appraisal of these in the scheme of the symbolic economy of the written word, the book, and the creation of a viable $21^{\text {st }}$ century African literature sets in relief a basic Nigerian limitation: "What of publishing? We write the books; to be available, they have to be competently distributed, not only in terms of libraries, but also commercially. Many of us here have had the experience of trying to meet the needs of the culturally marginalised by launching small, nonprofit publishing ventures in African literature. We find ourselves stopped short by the fact that the distribution network remains mainly the old colonial one" (Gordimer 2006: 4).

The renowned Nigerian novelist, Chukwuemeka Ike, traces the collapse of the publishing industry in Nigeria, after a beginning he appraises as auspicious, to the economic down turn experienced by the country in the 1980s. Identifying publishing as the most unregulated and undercapitalized industry in Nigeria, Ike remarks on the dominance of such foreign publishing companies such as Oxford University Press, Longman, Macmillan, Heinemann, Evans, even after the 1978 Nigerian Enterprises Promotion Decree which provided that at least $60 \%$ equity participation in book publishing must be by Nigerian nationals. However, as only a few emerging Nigerian writers today get their first works published by these companies, the bulk of current Nigerian writing is produced by much smaller publishing companies in the country often incapable of funding the production of texts without considerable financial input by the writer. Typically author-sponsored and author-distributed, and perhaps understandably typically blemished in production, current Nigerian writing in many ways exemplifies the implications of thwarted decolonization. Writ- 
ing in 1973, Atukwei Okai, then the president of the Ghana Association of Writers, drew attention to how the intractable difficulties of publishing in the continent led African writers to Western publishers. His appraisal of the Western gaze on African literature decades after remains insightful: "So all our best work [...] appears first to an audience which either regards us like some glass-enclosed specimen ... or like an exotic weed to be sampled and made a conversation piece ... or else we become some international organization's pet" (quoted in Kotei 2006: 405).

However, in his keynote address at the colloquium marking the twentieth anniversary of Soyinka's Nobel Prize, commenting on Chinua Achebe's dictum that the African writer and his/her audience live in the same place, Biodun Jeyifo notes the deterritorialization of the relationship between the African writer and his/her audience. Tracing this process paradoxically to the two decades since 1986, Jeyifo contends that given this "phenomenon of worldwide dimensions, a seismic, tectonic migration of persons, projects, ideas and movements around the globe" overwhelmingly detrimental to the developing world, "the production, dissemination and teaching of African literature have suffered unprecedented reversals" (Jeyifo 2006: 7). With the most important journals devoted to African literature based in the West, with the migration of most renowned African (especially Nigerian) scholars of that literature to Western institutions, with the consequent impoverishment of the teaching and discourse of that literature in Nigerian/African universities and newspapers, Nigerian writers and scholars, much like Nigerian sportsmen and women, meditate on their careers in the country as a preparation for the international market. This is especially so given the many outlets for glossy and error-free productions in the West, the fortune-transforming literary prizes and the inspiring conditions and incentives for productive and responsible scholarship. Jeyifo's evocation of some of the "penultimate barbarisms of arrested decolonization, postcolonial misrule and neoliberal globalization" resonates with apocalyptic terror and deserves to be quoted at length:

From all the available evidence, African literature is today much better taught outside than within. Indeed if we are to stare this particular discomfiting crisis squarely and unblinkingly in the face, we have to admit that, [with few significant exceptions noted] African literature is today very poorly taught in most African universities. For these are universities which are themselves buffeted by unprecedented crisis of under-funding, demoralization of faculty, staff and students, the rise of a pervasive culture of obscurantism and fetishistic pseudo-intellectualism and the attendant subversion of reason and critical thought as many senior teaching and research staff of academic departments come under the sway of evangelical chiliastic religious movements. (Jeyifo 2006: 8)

Writing on the mass migration of senior Nigerian scholars and writers to the West in their later years, Adebayo Williams is deeply elegiac about the impact of this "autum- 
nal exile," given the loss of the institutional validation which their presence could have lent to the Nigerian university system (Williams 2006: 5). The country is virtually the cradle of wandering minstrels and scholars, bards of many fatherlands, of multiple nationalities. But perhaps for the first time, Nigeria faces the critical crises of having most of the prominent members of its third generation of writers and critics already ensconced in institutions in the West. And the fiction of this generation of writers foregrounds the crisis. In Chimamanda Adiche's Purple Hibiscus a young Nigerian character, Obiora, disenchanted with the university system in which the mother teaches recommends flight, reasoning "By the time we get into university, the good professors will be fed up with all this nonsense and they will go abroad" (Adiche 2004: 232). In Gbenga Ajileye's A Whisper and a Silence (2004) the protagonist flees home and kindred on the mother's recommendation, given his excellent school result, that he become a lecturer! Blazoned on the podium at the colloquium marking the twentieth anniversary of Soyinka's Nobel Prize, "Migrating Words" seemed to epitomize the substance of ANA's meditation on the distinctive lot of literature in contemporary Nigeria.

2

Established in 1981 with Chinua Achebe as the founding president, the Association of Nigerian Authors (ANA) has aims and objectives rooted in the promotion of Nigerian literature, written and oral; the enhancement of the well-being of Nigerian writers and protection of their rights; the stimulation and development of indigenous talents, skill and intellectual powers; and the promotion and development of the book culture. However, in a not-thoroughly proof-read mission statement on the Association's website, the celebration of the outstanding achievements of Nigerian writers is placed beside a chastened appraisal of the current scene: "Nigeria (sic) literature is discussed these days largely in the context of book famine, a collapsed publishing industry and a profound suspicion that the superstructure which yielded the great international literature of the sixties and seventies has disappeared. In its place, a homegrown subsidy or vanity publishing has taken root, occasionally throwing up outstanding work." (Achebe on ANA website)

In the same statement, ANA notes its efforts, in a state of economic stress, to introduce to a large audience especially young writers through the publication of anthologies, the work of individual writers, and the annual journal, ANA Review, which it indeed intends to upgrade to a quarterly with an internet edition. ANA equally highlights the significance of its administration of a handful of prizes, considering them a crucial aspect of its formalization of a literary culture. And certainly quite apart from the ANA conventions and occasional conferences, some international in scope, in which the state of writing and the political and social environment in 
which that writing is done are discussed, ANA's position on the quality of writing in the country is made through its prizes. The 1998 ANA judges' report is for example remarkable in its thorough appreciation of the situation of the contemporary Nigerian writer publishing in the country and its recommendation of additional talents and responsibilities to Nigerian writers:

Because of the limited number of publishing outlets, most of the texts submitted in the various categories this year, excluding most of those published abroad, would more accurately be called printed rather than published works. Although one understands the authors' determination to reach the public, even when self-publishing seems necessary, this places responsibilities on the writer which are normally the duty of publishers. These responsibilities include critical reading and editing, and quality presentation. Authors must make it their responsibility to monitor every aspect in producing their book, from layout, to the cover design, to editing and proof-reading, bringing in expertise from other sources when necessary. (Chukura et al. 1998: 1).

Similarly, in 2004, when the prestigious Liquefied Natural Gas Prize intended for prose fiction was not awarded because no entry was considered worthy of the Prize, the Association's exhortation of Nigerian novelists to greater diligence and more painstaking production was memorably delivered!

With branches in nearly all the thirty-six states of the country and Abuja, the constant presence of ANA is felt by writers in the country through monthly readings and workshops, various publications, and state chapter annual conventions. The 2005 annual convention of the Imo State Chapter of ANA held at the state capital, Owerri, between the $6^{\text {th }}$ and $7^{\text {th }}$ of July turned out to be a representative ANA event: a convocation of writers, scholars, critics, and students of literature as well as other stake holders such as publishers, literary journalists, government officials, and patrons of the arts. The highlight of the occasion was certainly the keynote address by the eminent critic and scholar, Charles Nnolim, entitled "Contemporary Nigerian Fiction." Categorizing contemporary Nigerian fiction writers as the third generation of African writers, Nnolim noted their lack of a clearly defined thematic focus but commented, that "they have depicted a people adrift, hedonistic, cowed finally by the long incursion of the military in the body politic" (Nnolim 2005: 3). Nnolim identified Ben Okri as the harbinger of the contemporary Nigerian novel and considered as focal Okri's complication of Soyinka's earlier trope of a "wasted generation" through his character, Omovo, "I think ours is another damned generation of loss"; and remarked on Okri's influential depiction of Lagos as a symbolic setting epitomizing the "corruption, hedonism, debauchery and shenanigans, in contemporary Nigerian fiction" (Nnolim 2005: 4). Reading Maik Nwosu's Alpha Song (2001), Wale Okediran's Dreams Die at Twilight (2001), Omo Uwaifo's Fattening House (2001), Toni 
Kan Onwordi's Ballad of Rage (2004), Fola Arthur-Worrey's The Diaries of Mr Michael (2003), Jonah Ageda's God's Own Country (2004), and Chim Newton's Under the Cherry (2003) as representative third-generation Nigerian novels, Nnolim (2005:5) arrives at a conclusion that is far-reaching and sombre:

Contemporary Nigerian fiction depicts a society adrift and a people lost in the imbecilities of futile optimism, hoping that materialism and the pursuit of dirty lucre will compensate for the loss of the nation's soul; for the Nigeria we encounter in its contemporary fiction is a nation without a soul, without direction, without a national ethos - it is a rudderless ship a-sail amidst the jetsam and flotsam of a directionless voyage to nowhere.

As the ANA Imo Prose Fiction Prize announced at the convention was shared by Gbenga Ajileyi's A Whisper and a Silence and Gloria Ernest Samuel's epistolary novel Dear Kelechi (2005), I intend to devote some attention to the texts, appraising them partly in terms of Nnolim's observations but primarily to offer an indication of the quality of third generation Nigerian fiction produced in the country.

3

The very names of the winning authors probably tell important stories of the history of contemporary Nigeria as well as that of the contemporary Nigerian novel. For Imo state is at the heart of Igbo land and Ajileye is Yoruba and heads the Department of Yoruba at Alvan Ikoku College of Education, Owerri, while Samuel is a young Igbo lady (even if her names speak of mental migrations - on the cover page the Igbo name "Dike" is placed in parenthesis and conveniently forgotten thereafter) recently recruited as an academic member of staff in the Theatre Arts department at Imo State University, Owerri.

A Whisper and a Silence tells the timeless tale of a young man's desperation to understand himself and to be understood by others, of his estranging pathological insensitivity, of his torments and delusions of divine grandeur. It is precisely in making the unnamed lunatic-protagonist of the novel tell his own story that Ajileye demonstrates such deep compassion, breath-taking inventiveness, humor and penetrating insight into the nature of human perception and process of interpretation. The form par excellence for self-representation in novelistic discourse is the firstperson narrative. If the omniscient narrator strikes the reader as so conventional a strategy, thus setting in constant relief the fictionality of the story, the first-person narrator, on the other hand, enhances the illusion of actuality and immediacy. We are drawn forcefully into the events of the story, as we perceive reality (primarily) through the narrator; his/her interpretation of events presented as objective perception lures us to empathize with him/her. In the autobiography and the memoir this fiction 
culminates in the narrator's/author's arrogation to himself/herself the incontrovertible voice of history or even the oracular voice of God. Ajileye reclaims this device fully for fiction by using a lunatic as the narrator in $A$ Whisper and a Silence.

The protagonist narrator of the novel relives his experience of growing up as a child in a loveless home apparently to account for anti-social, even misanthropic, traits further exacerbated through indoctrination at school. Victimized by the sister's relentless verbal assaults, the brother's implacable hostility, the father's severities and, moreover, demonized by the mother's perverse faith, he lives an anguished life as a child at home. At the boarding house, first, the senior students' cruelties and later his own colleagues' conception of him as a hero-figure, bring to the fore character traits already latent in the narrator. Through out, Ajileye demonstrates the enduring formative influence of the family and school in creating a balanced or split personality. The terrors from which marijuana, cocaine and other forms of intoxication seem to provide a refuge are ultimately the terrors of the family, that crucial microcosm of society. Yet Ajileye's deep insight is in terms of the dialectic between societal and selfperception, between external ascription and self-conception.

Citing Lacan, Patrick Colm Hogan (1994: 104) contends that personal identity could be understood "not as some direct and immediate sense of self, but rather as a 'constitution' of the self, a sort of synthetic self-conception". Self-cognition is thus accessing a schema of the self and what is particularly

important to note about this self-schema is that it is in large part not the product of introspection, but rather of external attribution. In other words, to a considerable degree, I have been told what I am. My self-schema is formed by statements and attitudes of others to a far greater extent than we are usually aware. As Lacan put it, our self-image is "more constituting than constituted" [...] more a construction of us than a construction by us. (Hogan 1994: 104-5)

The conflict between the self-image and societal attribution is a central dilemma in the narrator's anguished striving towards self-knowledge in $A$ Whisper and a Silence.

The narrator's earliest attempt at self-introduction is significantly characterized by hesitations and doubts: "I really do not know who to tell you I am [...] the truth is that I do not think I really know $m e$ " (Ajileye 2004: 1-2). The frustration of the effort at self-knowledge arises from the realization of the lack of sovereignty in the human herd:

I do not understand why people would not even believe that I might have my own reasons for my actions. Why would people expect me to see things from their own perspective? [...] and, you may not believe it, the worst culprits have always been those people very close to me. Why are they always like that? Do friends and relations think they have a monopoly of rights over one's life? Or do they? (Ajileye 2004: 6-7) 
The tension between his striving to self-assertion and society's tyrannical impositions undermines his mental balance. Beginning with the premise that he is "a misunderstood person. Very misunderstood" (Ajileye 2004: 6), the narrator presumably offers the novel as retrieved history, in other words, the authentic account of events hitherto denied or suppressed by the legitimizing authority of society. His pretensions to objectivity are ostensibly drawn attention to early in the novel when the narrator expresses a certain disinclination for self-justification, instead assuming responsibility for his inadequacies, even exonerating God: "It [the novel] is my own attempt at vindicating God from any accusation of having just this one fault; the error of my creation" (Ajileye 2004: 1).

Yet the entire narrative is one of self-canonization. With a deep insight into the enormous powers of language in the human apprehension of reality, the narrator painstakingly re-names egoism, cruelty, savagery, theft, irresponsibility, inhumanity, seduction and even suicidal and murderous instincts to lure his audience to reconceptualize his alleged implication in these. The narrator notes: "I have always been in the habit of taking utterances apart and restructuring them to mean something else" (Ajileye 2004: 3). This is a focal remark on the fascinating power of discourse to (re)create reality. However, $A$ Whisper and a Silence does not only reveal egotistical impulses as inhibitions to attain truth; it is also primarily concerned with an authentic incapacitation to attain clarity of vision. It explores this disability in the form of neurosis. Ajileye's powers in the depiction of this state of mind are not only clinical but truly astonishing.

The psychiatrist's diagnosis which the narrator incidentally sets in relief by his attempts at its concealment; his temptations to "examine" the psychiatrist's prominent Adam's apple; his frequent loss of memory; his odd habitual mnemonic devices; his bizarre second visit to the psychiatrist that almost leaves the latter dead and his virtual inability to perceive the harm he does to the man: these constitute unmistakable early symptoms. But even more important is Ajileye's abiding insight that the true demonstration of madness is not merely the lunatic's delusion of normalcy but indeed of superiority to sane people. Inconsolable that other people refuse to appreciate his view, for example, the narrator after smashing his father's car into a tree under the influence of marijuana laments: "Most unfortunate was that my father might not believe that the smash was not really my fault. He might think it preposterous that the tree ran into the car not the other way [...] Why ever would I want to run into a tree when I was not a mad man or something like that?" (Ajileye 2004: 92)

Ajileye demonstrates, moreover, that the delusion of superiority to the sane is indeed a visionary disease that culminates in the deification of lunacy. The frustration in his bid to make his assailants understand in the episode above that his halfnakedness is no indication of madness but had been caused by the assaults of ants may well allude to madness itself as fiction, society's ascription, implicated in an 
error of judgment. But the nakedness is also after all a foreshadowing of the fullblown nudity of the novel's end equally presented by the narrator as a response to God's own injunction.

Ajileye's insight into the deepest compulsion of madness as its very deification is central in his exploration of that state of mind. This is set in relief in the episode in which the narrator is initiated into the smoking of marijuana: after the initial reluctance to inhale it, he confesses:

A funny feeling had started crawling from my fingers to other parts of my body. I called it funny because I found the feeling not quiet unpleasant. I suddenly started feeling light and excited. In fact, I felt great. I looked around me and all of a sudden I was in the garden of Eden and right in front of me was this creature [Makooze, a bully school mate, initiating him] smoking the apple wrapped in white paper. I remembered God's word warning me not to take of the apple but the creature in front of me was just too beautiful for me not to take the apple from him. He laughed as he put the wrap in my hand again. His voice was like God's own orchestra. (Ajileye 2004: 83-4)

Yet $A$ Whisper and a Silence is the story of the narrator's own apotheosis. Apparently casual utterances in this regard acquire enormous implications. When, for example, the narrator remarks about his brother, "He fought me, so why would he not fight ordinary angels" (Ajileye 2004: 9) the oblique reference is to the self-image as God. At the close of the novel, tormented, naked, poor Tom O'Bedlam, hounded by a legion of frightful goblins and demons, the narrator's self-apprehension moves from the elect of God to the embodiment of the Godhead, then to the successor of God:

I announce to the world that I am the new God, the father and God, the spirit is already in me. But they only laugh and hiss and shake their heads. The voice encourages me. It reminds me that their forebears also ignored my predecessor. So I continue to tell the world my name is Messiah [...] laughing at the mad creatures populating this world in their pitiable state of insanity. (Ajileye 2004: 178)

Madness inspires the ultimate fiction: the grandeur of the divine. The paradox is that by lunacy's insistence that its fictions are truths, the novel reveals its most basic truths about madness.

Interrogating canonical modes of representation in which the Other - especially the colonized native and the female - was ideologically perceived and constituted by an interested authority seeking to perpetuate a particular version of reality characterizes several postmodern projects. Appropriating the insight behind postcolonialism and feminism, Ajileye extends the category of marginalized voices and complicates the discourse on (self) representation. In writing $A$ Whisper and a Silence completely from the point of view of a lunatic and with a degree of compassion that sustains the 
illusion of objectivity while maintaining the appropriate critical distance to foreground the limitations of that mental disposition, Ajileye demonstrates that all forms of representations are necessarily mediations.

Insanity is equally a constant threat to the young female protagonist of Dear Kelechi, Iheoma, and her closest friend, Kelechi. For the former vilified by almost an entire society for childlessness (even when the indications are strong the husband may well be impotent) her letter to Kelechi is a palliative against insanity, subsisting in the conception of narration as a therapeutic gesture capable of redeeming both her and Kelechi from the horrors of their marriages: "I think about my looming ill health and the impending insanity which these pressing conditions may force me into. Only one thing can save me [...] and that is talking to you, hearing from you, sharing with you these problems, predicaments and challenges. That will equally help you appreciate your situation also" (Samuel 2005: 14). Again, Iheoma describes her marriage as "this relationship that is currently threatening to turn me into a psychiatric patient" (Samuel 2005: 17). Traumatized first by the husband's abandonment of her and their three children for the company of a white woman and then by the consequent suicide of their ten-year old son, Kelechi "spent three months in a psychiatric home in England" (Samuel 2005: 55). For Iheoma and Kelechi, marriage is an experience that epitomizes hell: men are the "bunch of bestial entities whom matrimony has branded our relations" (Samuel 2005: 17). Kelechi is finally driven to a total seclusion symbolic of the complete isolation of the grave. Iheoma, on her own part, goes through a pattern of humiliation that takes her through the hands of gynecologists, ritual priests, and self-acclaimed prophets, culminating in her chastened discovery of Christian fortitude. Yet none leaves her matrimonial home, inhibited by society's stigmatization of divorce, the maiden family's disinclination to stand the embarrassment of a daughter's divorce, the exaltation of Christian virtues, or simply choosing to remain faithful to an adolescent vision of an ideal marriage.

The temporal setting of Dear Kelechi is 1997, a year after the Beijing Conference. Through incremental repetitions, with Iheoma and Kelechi's experiences remaining focal but given depth, breadth and variety by Kelly's, Lizzy's, Ukachi's, Josephine's, and the several other women in the novel, Samuel apparently interrogates the presumption that education liberates the woman, even with the traditional mindset intact. The novel's depiction of the woman dilemma points to a combination of formidable conspiracies:

I blame the society that treats women as non-human or a chattel belonging to men.

I blame the culture that holds women responsible for domestic problems $[\ldots]$ its tying and resolution [...] I blame the religion that makes women submissive and dependent on the broken ribs of men. I blame the world for belonging to diverse beings (men and women) yet one reigns and the other is to be ruled (Samuel 2005: 85 , original emphasis). 
We are apparently in ideological axis. Yet the novel's occasionally tedious sermonizing on the theology of ideal Christian marriage reads rather like the exaltation of dogma; equally its paradoxical romanticization of the woman's place in the African tradition reads in part like the recommendation of stoicism or tragic acceptance as a resolution to the woman problem and in part like ideological transgression:

The African woman is strong, balanced, focused, and always in control. The men are always the men; in fact society leaves a lot around them; but the African women mould society $[\ldots]$ The watchword for every African woman should be: "This one shall also come to pass." And, indeed, our travails, predicaments and troubles all bow out at the appointed time (Samuel 2005: 116).

The presiding theme of Dear Kelechi is the denigration of the woman, and the novel offers many moving and memorable portraits of the woman as a casualty of tradition.

In many important respects, $A$ Whisper and a Silence and Dear Kelechi validate Nnolim's crucial observations about contemporary Nigerian fiction. With the possible exception of several female characters in Dear Kelechi resolutely seeking to transcend their limiting circumstances, many of the (male) characters in the two novels typify the category of whom Nnolim (2005:7) notes that for them the "pleasure of the flesh are of more moment than the essence of the spirit". Ajileye's (2004: 103) depiction of Lagos and his protagonist's comment on the boys (among whom he lives off the streets on first arriving in Lagos), "these guys were masters of the night" are virtually formulaic in Nnolim's charting of the still emerging topography of the work of Nigeria's third generation of novelists. The narrator's movement to Lagos in A Whisper and a Silence, like those of the characters in Dear Kelechi from one Nigerian city to another, and then from Nigeria to Kenya and then to England illustrate Nnolim's thesis:

Movement is a defining aspect of the new Nigerian novel. It defines a group of people on the move, flitting as it were from one Nigerian city to another, while also restless within the city (mainly Lagos) [...] There is a restlessness, a search for new experiences, an excitement about a new brave world of the internet, and the computer, hence the drift, the general unsettledness that sends characters on a quest which no one village or city can satisfy (Nnolim 2005: 10-1).

This restlessness, of course, is also inwardly a deep craving for distances beyond Lagos or any other Nigerian city; a deep dissatisfaction with the political and social conditions of the country; a yearning for a space where dreams are fulfilled; the urge that compels migrations.

However, Samuel's revival of feminist ideology and reaffirmation of Christian faith in Dear Kelechi may seem to interrogate some of Nnolim's claims in his particularly insightful study. For Nnolim had commented on the complete absence of the 
feminist ideology in the work of contemporary female Nigerian writers and discerned the death of God in current Nigerian writing. Nnolim's attitude towards the latter development is indictment: "In spite of the proliferation of churches, God is dead in recent Nigerian fiction, completely edged out by materialism and epicurean tendencies. Hedonism is the new non-Sunday religion. No major character in new Nigerian fiction goes to a religious service on Sunday and none kneels down to pray for God's intervention in moments of crisis" (Nnolim 2005: 22). Iheoma's response at the onset of the crisis that was to engulf her family reads like a deliberate refutation of Nnolim's claim (even if ironically in the same breath it affirms his observation on characteristic blemishes): "I've never been a prayerful person. But the urge to pray pulled me down on my kneels. (sic) 'Please God, don't let my enemies succeed in their plot against me..."' (Samuel 2005: 62, original emphasis). Typically, Nnolim had the scholarly meticulousness to characterize his paper as "tentative," given that the mapping of the terrain is still on-going and the contours still emerging. But even after the event, no study can possibly aspire to mention all writers in a generation let alone make them all focal. Literary prizes demonstrably aspire to be crucial in the symbolic process of the canonization of literary texts. The point of course is that like scholarship itself the enterprise cannot altogether exclude the perpetuation of biases.

Huggan has cited Bourdieu to identify literary prizes as legitimizing mechanisms that set in relief both the symbolic and material effects of the process of literary evaluation:

As Bourdieu suggests, prizes reflect as much upon the donors as their recipients; part of a wider struggle over the authority to consecrate particular works or writers, they are powerful indicators of the social forces underlying what we might call the politics of literary recognition. Far from offering tributes to an untrammeled literary excellence, prizes bring the ideological character of evaluation to the fore. (Huggan 2001: 118)

In The Other Side of the Mask (1999), the drama of the distinguished third generation Nigerian writer, Esiaba Irobi, this insight is located in the Nigerian situation. Frustrated in his desperate bid to win the national laurel for sculpture as an affirmation of his instinctive self-esteem, Irobi's artist-protagonist, Jamike, is intrigued to be told be one of the judges: "every prize, every laurel, every award has its own politics of acceptance [...] simply because a work wins an award does not mean it is better than all other works submitted. In fact, it does not even mean that [it] is a great work of art or a meaningful contribution to society, humanity." (Irobi 1999: 64-5)

Typically, ANA contemplates its prizes as a mechanism for consecrating excellence in writing, and reports by the ANA judges privilege the mastery and inventive use of language, and craftsmanship; they equally often exalt works with a potentially universal message. Reporting, however, that the awards have occasionally been mired 
in controversies, Akeem Lasisi highlights some of the contested points: "the actual choice of the judges, their number, the yardsticks used to asses the entries and the extent of the power of the assessors since they seem to be operating more on rules that are not very visible and which cannot be tampered with by strokes of their discretion" (Lasisi 1999: 27). Lasisi also notes anxieties expressed by some writers years back at the appointment of a judge with a Western background and doubts about the judge's knowledge of the elements of African literature; allegations about judges' prejudice against experimental works; and allegations that judges favor writers that are familiar to them. Lasisi's quotation of an ANA judge's response to the last allegation offers an insight into the procedures of the panel: "Our concern or focus is the work, not the author's name. When each judge has read all the works and drawn his/ her own short list, we meet and brainstorm extensively, in fact argue, and try to convince each other on certain recommendations that demand that at times" (Lasisi 1999: 27). At any rate, occasional contestations of the judges' decisions can be interpreted as recognition of the value of the ANA prizes (whose judges are changed every three years). In a context in which self-publishing is predominant; in which often the printed text reads like an early draft; in which the zeal to publish and contest is often deeper than the will to painstaking labor; and in which Western institutions of interpretation privilege their own pronouncements on Nigerian/African literature, the ANA prizes are indispensable measures of literary value in Nigeria.

\section{4}

In their presentations at the twentieth anniversary of Wole Soyinka's Nobel Prize both Nadine Gordimer and Biodun Jeyifo dwell on the crucial role of adequate education in the creation of a worthy literary culture in postcolonial Africa. Gordimer talks about literacy "beyond school primer and comic-book level," beyond the competence to "read state decrees and the graffiti that defies them" as indispensable for a readership capable of appreciating the new twenty-first century African literature that identifies with the people's own daily lives as well as the general world's mindopening literature (Gordimer 2006: 3, 5, 4). Jeyifo laments "a gross misuse of language that is part and parcel of a catastrophic decline in the quality of spoken and written language that itself is a product of system-wide malfunctioning of primary, secondary and tertiary education. All forms of writing today confront this grim fact, or rather interlocking sets of facts. And perhaps no modes of language use are more threatened by these facts of pervasive linguistic malaise than those associated with creative writing and critical discourse" (Jeyifo 2006: 9). Jeyifo's insight into the inherent linguistic and cultural crisis in the normalization of pervasive misuse and abuse of language as a reflection and reproduction of social contradictions and alienations is truly compelling. And one can conclude by meditating further, even if only fleetingly, on the 
ultimate barbarism that is the implication of Niyi Osundare's grave indictment on the quality of newspaper reviews in the country which Jeyifo quotes in some detail:

Not infrequently, review columns confront the reader with howlers such as "the second paragraph of the poem"; "this is X's second anthology of short stories" (for anthology read collection). And the work is praised as "simplistic" when what the writer means is "simple". There is a constant mention of works of "renown" authors, and reviews are hardly balanced in their handling of "strength and floors". Too monotonously, our critics "opine that ...". Almost invariably, what passes for a review is a bungled content summary without a single word on form and style. Quite often, the reviewer confuses biography with autobiography; "criticism" with "critique"; metaphor with simile; "summarily" with "summary". Achebe sometimes gets credit as the author of The Concubine! And the pages drip with cheap, whorish clichés! (quoted in Jeyifo 2006: 9 -10, original emphasis)

Dan Izevbaye's (1996: 12) construction of the history of research in the humanities in Nigerian universities highlights the increasing centrality of the media in research endeavors since the 1980s, given the decline in scholarly infrastructure. For many Nigerian academics and students the literary columns of Nigerian newspapers are central research tools and outlets. If their role as outlets is stressed and the malaise diagnosed recognized as even remotely reflective of the quality of critical discourse in our universities, then the dread of the pernicious perpetuation of the kind of "barbarisms" that both Osundare and Jeyifo highlight, passing through newspapers (back) to teachers and students, and imperceptibly seeping into even national scholarly journals is not an idle one. This is especially so given the considerable ease with which shockingly blemished texts easily join the happy company of texts prescribed and taught in some English departments in Nigerian universities. The ostensible reason is often the non-availability of "appropriate" texts; another compelling reason though is the lure of high percentage commissions offered by enterprising authors or publishers, or else "compassion" for a young writer. In any case, the threat is the perpetuation, even canonization, of the mediocre.

The Association of Nigerian Authors continues to provide the forum for Nigerian writers, literary scholars and critics of variegated plumage, in Nigeria and abroad, to flock together to work for the growth of Nigerian literature and Nigeria itself. If at the national level, the Association numbers among its main handicaps perennial financial problems and the lack of a secretariat in Abuja, the nation's capital city, its helplessness at the execution of Nigerian writers, Major General Mamman Vatsa and Ken Saro-Wiwa, by two different military dictatorships in the country remains a crucial failure. Yet with the cash value of the Association's prizes reviewed upwards; with its promotion of solidarity among Nigerian writers; its intervention on behalf of writers in cases of piracy; its visibility in crucial national discourse, its institutional prestige 
is on the ascendant. In large measure through the Association's interventions it is, fortunately, not silent yet at our national cultural front; but it threatens to become noisier or quieter there. For the quality of our creative writing will invariably remain proportionate to the quality of instruction in our schools especially in our universities and of our library resources.

Works cited

About the Association of Nigerian Authors. [O] < www.ana-ng.org/aboutANA.htm> Accessed: 01.06.2007. Attridge, Derek. 1992. Oppressive silence: J.M. Coetzee's Foe and the politics of the canon. In Karen R. Lawrence (ed.). Decolonizing Tradition: New Views of Twentieth-Century "British"Literary Canons. Chicago: University of Illinois, 212-38.

Adiche, Chimamanda Ngozi. 2004. Purple Hibiscus. London: Fourth Estate.

Ajileye, Gbenga. 2004. A Whisper and a Silence. Owerri: Taurus Books.

Chinweizu. 1998. Interview with Chinua Achebe. ANA Review October - December, 3.

Chukura, Lynn, Reuben Abati, and Tanimu Abubukar. 1998. ANA Literary Awards. Report of the Judges. (Unpublished).

Gordimer, Nadine. 2006. Turning the page: African writers in the $21^{\text {st }}$ century. Paper presented at the International colloquium on 20 years after the Nobel Prize in Literature: Governance and Development in Africa. Obafemi Awolowo University, Ile-Ife, Nigeria., 25-7 August.

Hogan, Patrick Colm. 1994. Mimeticism, reactionary nativism, and the possibility of post-colonial identity in Derek Walcott's Dream on Monkey Mountain. Research in African Literatures 25 (2): 103-19.

Huggan, Graham. 2001. The Postcolonial Exotic: Marketing the Margins. London: Routledge.

Ike, Chuwuemeka. [O] < www.sabre.org/publications/publishing-in-nigeria.pdf> Accessed: 01.06.2007. Irobi, Esiaba. 1999. The Other Side of the Mask. Enugu: ABIC.

Izevbaye, Dan. 1996. Critical engagements: Developments in African literary theory and criticism. The Post Express 30 November, 12.

Jeyifo, Biodun. 2006. The unfortunate children of fortunate parents: Reflections on African Literature in the wake of 1986 and the age of neoliberal globalization. Keynote address presented at the International colloquium on 20 years after the Nobel Prize in Literature: Governance and Development in Africa. Obafemi Awolowo University, Ile-Ife, Nigeria., 25-7 August.

Kotei, S. I. A. 2006. The book today in Africa. In Bill Ashcroft, Gareth Griffiths, and Helen Tiffin (eds.). The Post-Colonial Studies Reader. London: Routledge, 404-7.

Lasisi, Akeem. 1999. A jury in the Court of the People. The Comet, 28 August, 27.

Lock, Charles. 2006. Indirect rule and the continuities of Nigerian fiction. In Isidore Diala (ed.). The Responsible Critic: Essays on African Literature in honor of Professor Ben Obumselu. Treton, NJ: Africa World Press, 181-96.

Nnolim, Charles. 2005. Contemporary Nigerian fiction. Keynote address presented at the 2005 annual convention of the Association of Nigerian Authors (ANA), Imo State Branch, 6-7 July.

Samuel, Gloria Ernest. 2005 Dear Kelechi. Owerri: Cel-Bez Didatic Books.

Williams, Adebayo. 2006. The missing scholar as icon: Ben Obumselu and the crisis of intellectual modernity in Africa. In Isidore Diala (ed.). The Responsible Critic: Essays on African Literature in honor of Professor Ben Obumselu. Treton, NJ: Africa World Press, 1-14. 